\title{
Improving Learning Achievement on Family Medicine Topic by Increasing Learning Activity for Medical Students
}

\author{
Hanna Tabita Hasianna Silitonga*, Minarni Wartiningsih, Hebert Adrianto, Rahajoe Imam Santosa \\ Faculty of Medicine, Universitas Ciputra Surabaya, 60219, East Java, Indonesia
}

Received October 8, 2020; Revised December 10, 2020; Accepted March 8, 2021

\section{Cite This Paper in the following Citation Styles}

(a): [1] Hanna Tabita Hasianna Silitonga, Minarni Wartiningsih, Hebert Adrianto, Rahajoe Imam Santosa , "Improving Learning Achievement on Family Medicine Topic by Increasing Learning Activity for Medical Students, "Universal Journal of Educational Research, Vol. 9, No. 4, pp. 831 - 835, 2021. DOI: 10.13189/ujer.2021.090416.

(b): Hanna Tabita Hasianna Silitonga, Minarni Wartiningsih, Hebert Adrianto, Rahajoe Imam Santosa (2021). Improving Learning Achievement on Family Medicine Topic by Increasing Learning Activity for Medical Students. Universal Journal of Educational Research, 9(4), 831 - 835. DOI: 10.13189/ujer.2021.090416.

Copyright $\mathrm{C} 2021$ by authors, all rights reserved. Authors agree that this article remains permanently open access under the terms of the Creative Commons Attribution License 4.0 International License

\begin{abstract}
Family medicine approach is the competence that must be mastered by the medical student. But in reality, family medicine is a topic that is less in demand by students. Students are more interested in basic and clinical medical science, or students do not yet understand the application of this approach in medical practice. Therefore, lecturers need to improve in learning methods such as increasing learning activity to enhance the learning achievement of family medicine topics. The purpose of this study is to find increasing learning achievement by increasing learning activity in this subject. Research method in this study is quantitative descriptive with a cross-sectional approach. We use pre-test and post-test scores of 40 medical students who attended the family medicine class. The instrument used is a quiz question that amounts to 5 items in the form of vignette questions with MCQ options. Researchers analyzed data with the Wilcoxon test. The results of this study showed there was a significant difference in pre-test compared with post-test with $p<0.01 \quad(p=0.000)$. This study concludes that increasing learning activities can effectively increase medical students' scores on family medicine topics. It is needed to further research on other learning methods that can improve the achievement of student's learning related to this topic.
\end{abstract}

Keywords Learning Achievement, Family Medicine, Medical Students, Learning Activity

\section{Introduction}

Globally, family medicine (FM) is a medical specialty that provides comprehensive and sustainable health care for patients and their families. It integrates biological, clinical, and behavioral sciences with a scope covering all ages, genders, organ systems, and disease entities [1]. The World Organization of Family Physicians (World Organization of National Colleges, Academies and Academic Associations of General Physicians/Family Physicians [WONCA]) defines "family physicians" as physicians primarily responsible for providing comprehensive health care to every individual seeking medical care and coordinating services with other health workers if necessary [1].

The family medicine approach utilizes multidisciplinary and interdisciplinary medical sciences. The target is the patient as part of the family. FM is comprehensive, integrated, sustainable, and proactive medical services and focus more on the maintenance and improvement of the health of all family members as one unit, not only on the age group, gender, organs, type of disease, or specific complaints. The doctor who performs this service is usually general practitioners. The Center for Public Health (Puskesmas) not only conducts health services inside the building but also visits family in its work area. There is a lot of evidence that suggests the family approach can complement and strengthen the patient's practice as an 
individual. Basic Health Research Data (Riskesdas) shows evidence about that in the management of stunting and hypertension [2].

According to Indonesian physician competency standards (Standard Kompetensi Dokter Indonesia [SKDI]), medical students have to master the competencies of the family medicine approach. It includes the scope of the family doctor, definition and type of family, genograms, holistic and family diagnostic skills, and the level of doctor involvement in patients and families. In Indonesia's medical education, usually, this competency is given at the undergraduate academic stage, then experiences directly during the undergraduate professional phase. By mastering this subject, students can become doctors following the competency standards of doctors in Indonesia. However, the implementation varies according to the prevailing medical education system in their respective countries and universities. For example, at Shifa College of Medicine in Islamabad, Pakistan, a family medicine practice with the theme of school health care, nutrition, communication skills are performed in year four by diving into the field to help general doctors conducting examinations in schools [3].

However, in medical studies, the material of medical science is often more attractive to students than the science of family medicine. Some of the assumptions from students are that they do not understand the purpose and application and do not feel the need to engage on this topic. In the University of KwaZulu-Natal, last year students thought that the primary clinical role of family physicians was only general doctors $(41 \%)$, and was unaware of the difference between General Practitioners and family physician specialists. FM in that country is a specialty registered with the HPCSA, but students do not understand the usefulness of this enrolment for their careers. The majority of students have limited interest in pursuing a long term career in FM. Final-level students have a low awareness of the profession of family medicine, and this may be due to the low level of FM excellence in general, among other specialties [4].

Although it differs in curriculum and the definition term of family medicine used, it does suggest that low interest in family medicine can influence students' future decisions. The inability of students to understand this approach of family medicine will make students potentially not do this principle when they become a co-assistant doctor and also when becoming a doctor and competence as a doctor following SKDI will be not achieved. There are various efforts to increase students' interest in this topic. One of them is to introduce FM in new student matriculation and also include them in FM interest groups (FMIG) [5].

It is therefore vital to find a learning model for teaching principle of a family medicine approach that can improve student understanding. The purpose of this research is to see whether increasing learning activity in class is suitable for students to understand the principles of family medicine and be able to improve the learning achievement of students.

\section{Materials and Methods}

The design of this research was quantitative descriptive with a cross-sectional approach using secondary data that was the student's pre and post-test scores. The population in the study was 45 medical students who took family medicine courses. The sample in this study was total sampling, but in the end, there were only 40 students who filled the pre and post-test. The instrument used in this study was a quiz consisting of 5 vignette questions in the form of Multiple Choice Question (MCQ). The procedure was students filled out a pre-test. Lecturer provided materials using PowerPoint and did learning activities in the classroom (created family genograms). Then the lecturer gave one case of the patient, and the student had to diagnose the problem with the approach of the family medicine. After the activity, there was a discussion about the topic. At the end of class, students filled out a post-test. Data were analyzed using IBM SPSS Statistic 25.

\section{Results}

Table 1 shows the distribution of answers obtained from pre and post-tests. The question with the least number of correct answers is the Q2 question, which is about the family form of the given case. Meanwhile, Q4 pre-test questions about the internal risk aspects of patients can be answered correctly by $35 \%$ of students. In the average number of answers, $36 \%$ answered correctly. In the post-test, there was an increase in the mean of the correct answer to all questions. As many as $90 \%$ of students can answer correctly for Q4 questions. 
Table 1. Distribution of Answer of Pre and Post Test

\begin{tabular}{|c|c|c|c|c|c|}
\hline \multirow{2}{*}{ Question } & \multirow{2}{*}{ Correct Answer } & \multicolumn{2}{|c|}{ Pre-test } & \multicolumn{2}{|c|}{ Post-test } \\
\hline & & $\mathrm{n}$ & $\%$ & $\mathrm{n}$ & Q \\
\hline \multirow{3}{*}{$\begin{array}{l}\text { Q1. What is the most appropriate statement } \\
\text { according to the following Genogram? }\end{array}$} & Yes & 13 & 33 & 28 & 70 \\
\hline & No & 27 & 68 & 12 & 30 \\
\hline & Total & 40 & 100 & 40 & 100 \\
\hline \multirow{3}{*}{$\begin{array}{l}\text { Q2. What is the family type of the following } \\
\text { cases? }\end{array}$} & Yes & 11 & 28 & 33 & 83 \\
\hline & No & 29 & 73 & 7 & 18 \\
\hline & Total & 40 & 100 & 40 & 100 \\
\hline \multirow{3}{*}{$\begin{array}{l}\text { Q3. Which includes functional aspects in } \\
\text { holistic and family diagnosis of the following } \\
\text { cases? }\end{array}$} & Yes & 14 & 35 & 31 & 78 \\
\hline & No & 26 & 65 & 9 & 23 \\
\hline & Total & 40 & 100 & 40 & 100 \\
\hline \multirow{3}{*}{$\begin{array}{l}\text { Q4. Which includes aspects of internal risk in } \\
\text { holistic and family diagnosis? }\end{array}$} & Yes & 20 & 50 & 36 & 90 \\
\hline & No & 20 & 50 & 4 & 10 \\
\hline & Total & 40 & 100 & 40 & 100 \\
\hline \multirow{3}{*}{$\begin{array}{l}\text { Q5. What is the level of involvement of } \\
\text { doctors in the patient's family from the } \\
\text { following cases? }\end{array}$} & Yes & 13 & 33 & 27 & 68 \\
\hline & No & 27 & 68 & 13 & 33 \\
\hline & Total & 40 & 100 & 40 & 100 \\
\hline \multirow{3}{*}{ Mean } & Yes & 14.2 & 36 & 31 & 78 \\
\hline & No & 25.8 & 65 & 9 & 23 \\
\hline & Total & 40 & 100 & 40 & 100 \\
\hline
\end{tabular}

With normality test Shapiro-Wilk, the data were not distributed normally $(\mathrm{p}=0.000)$. Therefore, the researcher used a comparison test between pre and post-test with a non-parametric test that is the Wilcoxon test. The result was a value of $p<0.05$, which means there is a significant difference between the pre and post-test scores. The reason data were not homogenous because there was a gap in the academic ability of students in the classroom.

Table 2. Wilcoxon Test of Pre and Post-Test

\begin{tabular}{|c|c|}
\hline $\mathrm{Z}$ & -4.986 \\
\hline Asymp. Sig. (2-tailed) & .000 \\
\hline
\end{tabular}

The results of this study show there was an increase in student knowledge of the principles of family medicine. Through genogram-making activities and case studies, students were able to understand the approach of family medicine with satisfactory results. Increasing learning activities were effective methods to give students an understanding of the application of family medicine principles. This kind of learning method is perfect when compared to one-way learning methods from lecturer to the student. With this method, there is a reciprocal relationship between lecturers and students.

The exciting thing is in terms of the manufacture of genograms. In the bloom level, students should be at the "create" level that creates something new from the concept obtained in this case which is a genogram that suits their own family. But the post-test results found that the increasing incorrect answers from pre to post-test were not as much as other post-test questions. The students made genograms from their families, and if no families were suffering from certain diseases, their genograms were made simple. When applied to the case of a slightly complicated patient, the student is not able to use the concept of the Genogram as a whole. Type of family is the question that has increased the number of correct answers compared to other items. The concept of family type is an easy-to-understand concept so that when applied to the vignette question, students could answer it correctly.

\section{Discussion}

Although change is the norm in higher education, large group lecture remains the same [6]. A large group lecture is a mechanism to save costs where one person teaches many students in a lecture hall with a span of 2 hours. It is a challenge to maintain the attention of students and change the passive role of students to be active. Many research in the field of medical education also showed the same concerns [7-11]. Some examples of active learning in the medical context are making presentations in the form of poems, songs, and stories [8]. Lecturers can also have discussions outside the classroom [11] or create small group discussions [12] or provide Problem-Based Learning for students [13].

Active learning reduces achievement gaps in test scores 
and graduation rates. High-quality, widely applied active learning reduces or eliminates achievement gaps [14]. There are also findings that interventions have little impact on all variables [15]. Besides, results suggest that a supportive and active learning environment is one of the essential factors in promoting learning for some groups. However, background knowledge, academic self-regulation skills, and lecturer teaching experience are also considerations in student learning achievement. [16].

The flipped classroom is an innovative learning model and is different from traditional face-to-face learning methods. Thus, teachers usually have prepared the content of their lessons through digital materials, and their students will access these materials before the course. This approach centers on students' support active learning, improves classroom learning time, provides a richer and more flexible learning environment through technology infrastructure, and becomes a component of mixed education. Scores for students in experimental groups concerning academic performance and engagement were higher than scores for those in the control group, and the differences between those groups were statistically significant [17]. Online materials, instructor, and peer roles are fundamental elements that produce high-quality, active learning. Few students report some of the problems that are considered the main obstacles faced by some students, which are computer skills and time-consuming tasks [18].

Electronic learning (e-learning) shows an increase in active learning that can be demonstrated by improved achievement. The results showed not only pre and post differences but also a more positive attitude towards learning [19]. The study found significant positive effects on trainees' self-esteem in reactions, learning, behavior, and organizational outcomes. The researcher used this result for a summative evaluation of the effectiveness of experience learning by Kirkpatrick. The consequences of encouraging increased confidence shake up the scientific achievement but in addition to establishing the establishment of self-administration behaviors that can serve students during their lifetime, in academic and vocational efforts [20]. Some studies show the same result in learning achievement $[21,22]$.

Teaching methods by improving classroom activities can also be incorporated into the curriculum. A study shows a small group active learning approach involving three stages: concept mapping, peer review of students, and evaluation of student groups. From this study obtained, there was a significant statistical achievement in critical thinking and teamwork among students [23]. Another evidence that shows the outcome of active learning is students' commitment to sustainable development [24].

Another study found that nearly half of medical students are open to the idea of practicing family medicine. The things that can improve this request are the medical experience in rural areas and the positive experience. Therefore, rural affairs will be a strong driver in the learning of this [25]. Factors associated with the study style preferences of medical students in public health medicine courses include age, race, father's job, maternal employment, and pre-university education. Also, early exposure to the field is one of the factors that encourage medical students to learn about family medicine. Therefore, proposals to make field visits more often can be considered [26]. Meanwhile, in the classroom, other ways in increasing learning activity of class are video-based [27] and think, pair, and share method [28].

\section{Conclusions}

Through increasing learning activities such as genogram making and case studies in family medicine courses, students experience an increased understanding of the principles of family medicine. Improved knowledge of holistic diagnostics and families prepares students to face the world of co-ass and also become doctors later. More research is needed on family medicine learning methods to be more readily accepted and applied by students. The question that gets the number of the least correct answers is the fifth question about the involvement of doctors in the patient's family. The result indicates that students have not been able to assess this concept in vignettes. The cause of the problem is likely that the idea is still too general, or the method of learning to be seen to students still needs improvement.

\section{REFERENCES}

[1] Rakel RE, and Rakel DP. Family Physician. In: Textbook of Family Medicine Ninth Edition. 9 th ed. United States: Elsevier Saunders; 2016: p. 3-16.

[2] Kementerian Kesehatan Republik Indonesia. Pedoman Umum Program Indonesia Sehat Dengan Pendekatan Keluarga [Internet]. 2016 p. 81. Available from: https://www.google.com/url?sa=t\&rct=j\&q=\&esrc=s\&sour ce $=$ web\&cd $=\& v e d=2$ ahUKEwiR-e--5ZPsAhUGeisKHZxZ AtIQFjABegQIAxAC\&url=https \%3A\%2F\%2Fwww.kemk es.go.id $\% 2$ Fresources $\% 2$ Fdownload $\% 2$ Flain $\% 2$ FBuku $\% 25$ 20 Program $\% 2520$ Indonesia $\% 2520$ Sehat $\% 2520$ dengan $\% 25$ 20Pendekatan $\% 2520$ Kelu

[3] Naseem S, Ghazanfar H, Fatima SH, and Ghazanfar A. Medical Students Assisted Health Checkup And Focused Health Education - An Integration Of Community And Family Medicine. Journal of Shifa Tameer-e-Millat University. 2019;1(1):27-31.

[4] Omed Ali R, Ross AJ, and Nkabinde TC. Knowledge Of Final-year Medical Students At The University Of KwaZulu-Natal About Family Medicine, And Long-term Career Choices. South African Family Practice. 2019;61(1):5-10. 
[5] Kost A, Kardonsky K, Cawse-Lucas J, and Sairenji T. Association Of Family Medicine Interest At Matriculation To Medical School And FMIG Participation With Eventual Practice As A Family Physician. Family Medicine. 2019;51(8):682-6.

[6] Roberts D. Higher Education Lectures: From Passive To Active Learning Via Imagery? Active Learning in Higher Education. 2019;20(1):63-77.

[7] da Silva JB, Sales GL, and de Castro JB. Gamification As An Active Learning Strategy In The Physics Education. Revista Brasileira de Ensino de Fisica. 2019;41(4).

[8] Singh K, Bharatha A, Sa B, Adams OP, and Majumder MAA. Teaching Anatomy Using An Active And Engaging Learning Strategy. BMC Medical Education. 2019;19(1):18.

[9] Fitri Y, and Refnywidialistuti R. Perbedaan Hasil Belajar Matematika Siswa Menggunakan Strategi Active Learning Dengan Cara Giving Questions And Getting Answers Dengan Pembelajaran Konvensional Di Kelas X Sma Ekasakti Padang. Math Educa Journal. 2019;2(2):191-205.

[10] Kadam DM, and Sejao AV. Case-Based Learning Versus Traditional Didactic Lecture In Community Medicine To Teach Vector-Borne Diseases "malaria And Dengue": Interventional Study. International Journal Of Community Medicine And Public Health. 2019;6(2):836.

[11] Kennedy DR. Redesigning A Pharmacology Course To Promote Active Learning. American Journal of Pharmaceutical Education. 2019;83(5):875-81.

[12] Sinnayah P, Rathner JA, Loton D, Klein R, and Hartley P. A Combination Of Active Learning Strategies Improves Student Academic Outcomes In First-year Paramedic Bioscience. Advances in Physiology Education. 2019;43(2):233-40.

[13] Kerboua KE, and Djenouhat K. Could The Hybrid Form Of Lecturing And Active Learning Be Used As A Curricular Tool For Medical Education Of Immunology In Algeria? American Journal of Immunology. 2019;15(1):36-9.

[14] Theobald EJ, Hill MJ, Tran E, et al. Active Learning Narrows Achievement Gaps For Underrepresented Students In Undergraduate Science, Technology, Engineering, And Math. Proceedings of the National Academy of Sciences of the United States of America. 2020;117(12):6476-83.

[15] Alrashidi O. The Importance Of Various Indicators Of Active Learning On The Enhancement Of Saudi Students' Motivation And English Achievement: An Experimental Study. English Linguistics Research. 2020;9(1):40.

[16] Reinke NB. Promoting Student Engagement And Academic Achievement In First-year Anatomy And Physiology Courses. Advances in Physiology Education. 2019;43(4):443-50.
[17] Talan T, and Gulsecen S. The Effect Of A Flipped Classroom On Students' Achievements, Academic Engagement And Satisfaction Levels. Turkish Online Journal of Distance Education. 2019;20(4):31-60.

[18] Alamri, MM. Students' Academic Achievement Performance And Satisfaction In A Flipped Classroom In Saudi Arabia. International Journal of Technology Enhanced Learning. 2019;11(1):103-19.

[19] Robroo I. The Effect Of Using E-learning For Enhancing Active Learning Of Pre-service Teachers. International Journal of Information and Education Technology. 2019;9(11):799-804.

[20] Liao PW. Experiential Learning Is An Effective Training Model To Improve Self-esteem. Humanities and Social Sciences Reviews. 2019;7(5):165-73.

[21] Aji CA, and Khan MJ. The Impact Of Active Learning On Students' Academic Performance. Open Journal of Social Sciences. 2019;7(3):204-11.

[22] Jeong JS, González-Gómez D, Cañada-Cañada F, Gallego-Picó A, and Bravo JC. Effects Of Active Learning Methodologies On The Students' Emotions, Self-efficacy Beliefs And Learning Outcomes In A Science Distance Learning Course. Journal of Technology and Science Education. 2019;9(2):217-27.

[23] Slieman TA, and Camarata T. Case-Based Group Learning Using Concept Maps To Achieve Multiple Educational Objectives And Behavioral Outcomes. Journal of Medical Education and Curricular Development. 2019;6:238212051 987251.

[24] Buil-Fabregá M, Casanovas MM, Ruiz-Munzón N, and Filho WL. Flipped Classroom As An Active Learning Methodology In Sustainable Development Curricula. Sustainability (Switzerland). 2019;11(17).

[25] Bien A, Ravens-Taeuber G, Stefanescu MC, Gerlach FM, and Güthlin C. What Influence Do Course At Medical School, And Personal Experience Have On Interest In Practicing Family Medicine? - Results Of A Student Survey In Hessia. GMS Journal for Medical Education. 2019;36(1):1-19.

[26] El Shafei AM, and El Lawindi, MI. Strengthening Public Health Education of Undergraduate Medical Students Through Early Primary Healthcare Services' Association. International Journal Of Community Medicine And Public Health. 2020;7(8):2979.

[27] Sulaiman WMH Bin, Jumintono, Wahyuniati CFS, et al. Quickly Understanding On Progressive Muscle Relaxation With Video-based Learning In Secondary School Students. 2020;8(5):181-5.

[28] Sumiyardi D. Improving Students' Activities And Achievements Of Learning English Using Think Pair Share Model In Smpn Maur In The Academic Year Of 2019/2020. Jurnal Perspektif Pendidikan. 2019;13(2):121-8. 